
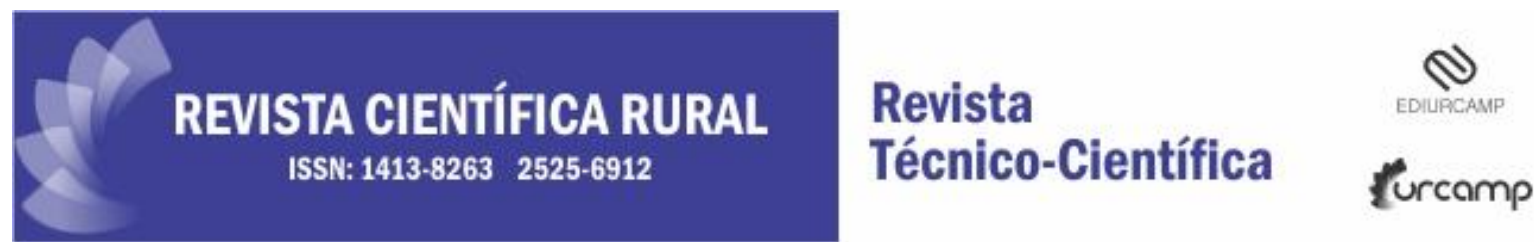

\title{
PROFILE OF ANIMAL PROTEIN CONSUMERS AND CHARACTERIZATION OF FISH CONSUMPTION IN A SEMIARID REGION, BRAZIL
}

Carlos Yure Barbosa de Oliveira ${ }^{1}$, Allysson Winick da Silva², Emerson José da Silva Oliveira ${ }^{3}$, João Lucas Oliveira Rocha ${ }^{4}$, Maria Mirele Nogueira Barbosa², Larissa Joyce Lopes Nunes², Renata Akemi Shinozaki-Mendes ${ }^{5}$

${ }^{1}$ Doutorando em Recursos Pesqueiros e Aquicultura, Universidade Federal Rural de Pernambuco (UFRPE); ${ }^{2}$ Engenheiro de Pesca, Universidade Federal Rural de Pernambuco (UFRPE); ${ }^{3}$ Graduando em Engenharia de Pesca, Universidade Federal Rural de Pernambuco (UFRPE); ${ }^{4}$ Mestrando em Aquicultura, Universidade Federal de Santa Catarina (UFSC); ${ }^{5}$ Doutora em Biologia Animal, Universidade Federal Rural de Pernambuco (UFRPE)

ABSTRACT: The present study characterizes animal protein consumers, with emphasis on fish consumption in the semiarid region of Brazil. No significant differences were observed in our analysis of the frequency of fish consumption as a function of education level ( $p=0.1362)$, with a mean consumption across all levels of $4.78 \pm 2.05$ meals per month and a median of four meals per month. In the analysis of fish consumption as a function of age, gender, education level, income and product preference, in a multiple model, the most influential variable was found to be product preference $(P$-value $=0.00005$, Durbin-Watson $=2.0594)$, with no statistic difference regards to age, gender, schooling or income $(p=0.6987)$. In this semiarid region, there is a predominant preference for bovine, with fish being the third most consumed protein. It is essential to maintain and promote campaigns to encourage fish consumption, as well as to promote public investment in order to reduce production costs and, consequently, ensure that fish is always a readily available option for consumers. These and other actions are necessary in order to prevent the economic factor from becoming the deciding factor for consumption decisions, in the short, medium and long term.

Keywords: Preference; food; protein consumer; social class 


\section{PERFIL DO CONSUMIDOR DE PROTEÍNA ANIMAL E CARACTERIZAÇÃO DO CONSUMO DE PESCADO EM UMA REGIÃO SEMIÁRIDA DO BRASIL}

RESUMO: O presente estudo objetivou a caracterização dos consumidores de proteína animal, com ênfase no consumo de pescado no Semiárido. Ao analisar a frequência de consumo de pescado em função da escolaridade, não se observou diferenças significativas ( $p=0,1392)$, sendo a média de consumo, para qualquer classe, de 4,78 $\pm 2,05$ e a mediana de 4 vezes por mês. A relação entre consumo de pescado e local de compra, houve diferença significativa, sendo o maior consumo associado à compra direto do pescador. Analisando o consumo do pescado em função da faixa etária, gênero, escolaridade, renda e preferência pelo produto, utilizando um modelo múltiplo, a preferência pelo pescado foi a variável de maior influência ( $P$-valor = 0,00005; Durbin-Watson = 2,0594), não havendo distinção entre as demais classes etárias, os sexos, a escolaridade e tampouco a renda ( $p=0,6987$ ). Nesta região semiárida a preferência pela carne bovina é predominante, ficando o pescado em terceiro lugar no ranking. E indispensável manter e promover campanhas de incentivo ao seu consumo, bem como agenciar investimento público para o barateamento na produção e em consequência, garantir que o pescado esteja sempre presente na mesa do consumidor. Essas e outras ações impedem que o fator econômico se torne, em curto, médio ou longo prazo, o principal fator para decisão no consumo.

Palavras-chave: Preferência, alimento, consumidor de proteínas, classe social.

\section{INTRODUCTION}

As incomes rise and the world population grows, the demand for animal protein increase. Meat, the main protein source of the human diet, are notable for its near-constant presence in consumer's daily diets, a fact that is directly related to the nutritional characteristics, high levels of purchasing power, palatability and consumer demands. However, meat production is already associated with a large environmental impact, in addition, the omega- 6 to omega-3 fatty acids ratio on the diets can directly influence on human health. Therefore, sustainable sources of animal protein and that can contribute to reducing the omega- 6 to omega- 3 fatty acids ratio are being investigated (SIMOPOULOS, 2006; CARVALHO et al., 2008; McCLENACHAN et al., 2016; LÓPEZ-VICENTE et al., 2019).

Aquaculture in Brazil grew approximately 5.6\%, corresponding to 2.6 million tons, between 2013 and 2014. In the same period, the Brazilian population grew by 
$0.9 \%$, resulting in an increase in the supply of fish (FAO, 2017; IBGE, 2015). The Northeast region of Brazil was responsible for $17.4 \%$ of the total national fish production, with the state of Pernambuco accounting for about $8 \%$ of the region's production, largely attributable to the major fish farming centers along the lower reaches of the São Francisco River (RIBEIRO-NETO, 2016).

Although the benefits of fish consumption to human health are well-known, other sources of animal protein are still often preferred by consumers. According to the Agricultural Economics Institute (IEA; 2016) and the O'Quinn et al. (2018), the per capita consumption of poultry and beef reached 43.25 and $38.59 \mathrm{Kg}_{\mathrm{year}}{ }^{-1}$ respectively. Fish consumption accounted for only $14.4 \mathrm{Kg} \mathrm{year}^{-1}$, according to the Ministry of Agriculture, Livestock and Supply (MAPA; 2015).

Although Aquaculture has advanced considerably in Brazil, Livestock still remains the main agricultural activity of animal production (SALTON et al., 2014). This is possibly related to the great territorial extension of the country and traditional customs (BALBINO et al., 2011). However, other factors may be related not only to productive characteristics but also to fish consumption, and are still little known in Brazil, especially in the semiarid region. In this context, the present work aims to characterize animal protein consumers, analyzing the main obstacles and potentialities, with an emphasis on fish consumption in the semiarid region of Pernambuco.

\section{MATERIAL AND METHODS}

A total of 160 people was interviewed during the $17^{\text {th }}$ Trade Fair for Industry, Commerce and Services Serra Talhada (ExpoSerra), held in the city of Serra Talhada, Pernambuco state, Brazil (038 17' 34" W, 07 59' 7" S), from July 14 to 16, 2016.

Descriptive statistics were used for the mean, median and standard deviation from the mean for the frequency of fish consumption according to education level and place of origin of the product. In order to evaluate possible statistical differences between the treatments $(p<0.05)$, we initially tested for distribution errors (Shapiro- 
Wilk test) and homoscedasticity of the variances (Bartlett's test) (ZAR, 2010). As the variances were homogeneous $(p=0.5532)$, but not normal $(p<0.0001)$, the nonparametric Kruskal-Wallis test was used and median values were compared using the Student-Newman-Keuls test (Zar, 2010; Mendes, 1999).

The frequency of monthly consumption was evaluated according to age group (the first group consisting of interviewees under the age of 18, 7 groups between 18 to 60 years separated by 5 year periods, and those over 60 years), gender (male or female), household income level (using monthly minimum wage as a base, the groups were enumerated as $\leq 1,2-3,4-5$ or $<5$ minimum wages), education level (complete or incomplete levels of elementary education, high school or higher education) a multiple model with dummy variables, as described:

$$
\begin{aligned}
\text { Consumption } & =\beta_{0}+\beta_{1} \text { age group }+\beta_{2} \text { Gender }+\beta_{3} \text { Education Level }+\beta_{4} \text { Income } \\
& +\beta_{5} \text { Preference }+\varepsilon
\end{aligned}
$$

Wherein $\beta_{n}$ are the parameters of the model and $\varepsilon$ the error associated with each observation. To evaluate the consistency of the model, we used the " $F$ " statistic of the variance analysis for regression $(p<0.05)$ and the residual analysis based on the Durbin-Watson statistic (Mendes, 1999).

\section{RESULTS}

The interview sample consisted of 80 male and 80 female subjects, grouped by age as expressed below. The male interviewees presented two modal classes, between 30 and 34 and between 51 and 55 years of age. Among the women, the age groups of 35 to 40 and over 60 years of age were the most representative. Analyzing the monthly frequency of fish consumption as a function of the nine age groups considered (Figure 1), there is a clearly lower frequency of consumption among the younger interviewees, from those less than 18 to 30 years of age. The highest frequencies, in turn, are not linked to the older age groups, being the fourth, fifth and sixth among age groups in consumption. 


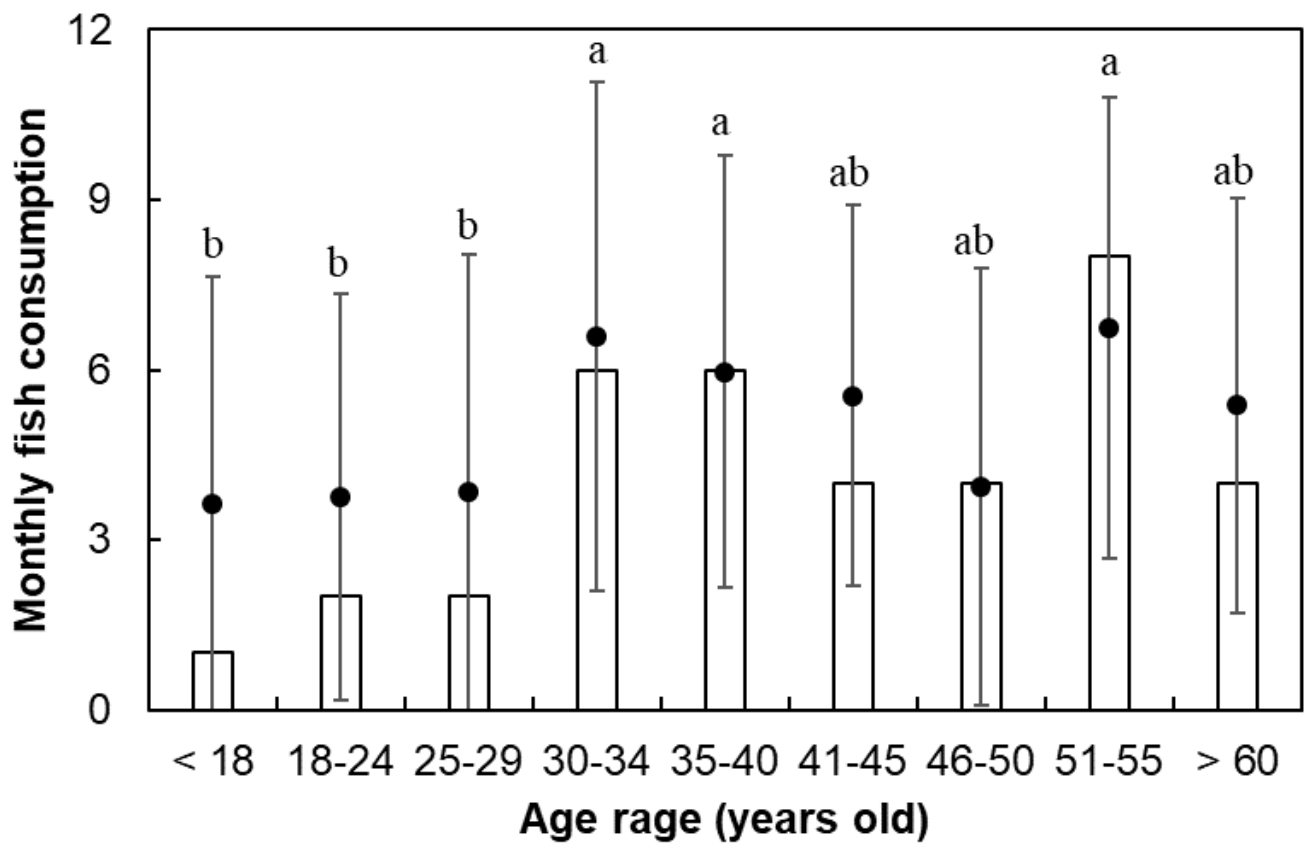

Figure 1. The frequency of monthly fish consumption in relation to consumer age groups in Pernambuco's semiarid region in the year 2016. The bars indicate the median values; circles indicate mean values with standard deviation. Equivalent letters indicate statistical equality $(p>0.05)$ using non-parametric ANOVA (Kruskal-Wallis test) followed by the Student-Newman-Keuls test.

Our analysis of the frequency of fish consumption showed no statistical differences according to education levels $(p=0.1392)$, with the mean consumption for all levels being $4.78 \pm 2.05$ and the median of 4 meals per month.

Our research also indicated no statistically significant difference in fish consumption as a function of household income levels ( $p=0.6987)$. This indicates that fish can be considered a consumer good in which the frequency of consumption is not affected by the income level of the consumer.

In our examination of fish consumption and the place of purchase (Figure 2), we observed a significant difference associated with purchasing locations, indicating lower consumption levels associated with purchases from stores and markets, and higher consumption associated with the direct purchase from the angler, followed by bars and restaurants and fairs. 


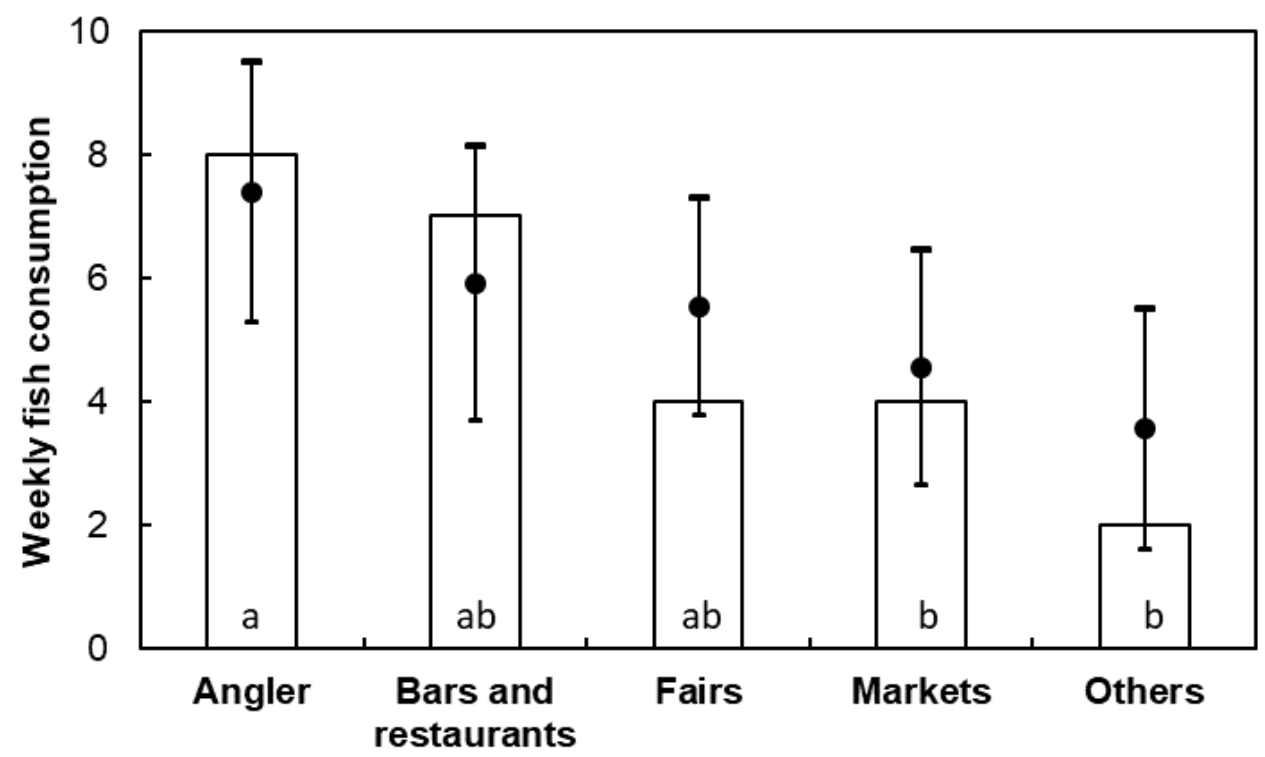

Figure 2. Weekly fish consumption in relation to place of purchase in Pernambuco's semiarid region in the year 2016. The bars indicate the median values; circles indicate mean values with standard deviation. Equivalent letters indicate statistical equality $(p>0.05)$ using non-parametric ANOVA (Kruskal-Wallis test) followed by the Student-Newman-Keuls test.

By comparing the frequency of monthly fish consumption with the consumer's preferred type of animal protein (Figure 3), we observed that in Pernambuco's semiarid region the preference for bovine is predominant, with fish ranking third in interviewees preferences. We noted no direct relationship between fish preference and consumption, with the frequency of consumption being close to 6 times a month. 


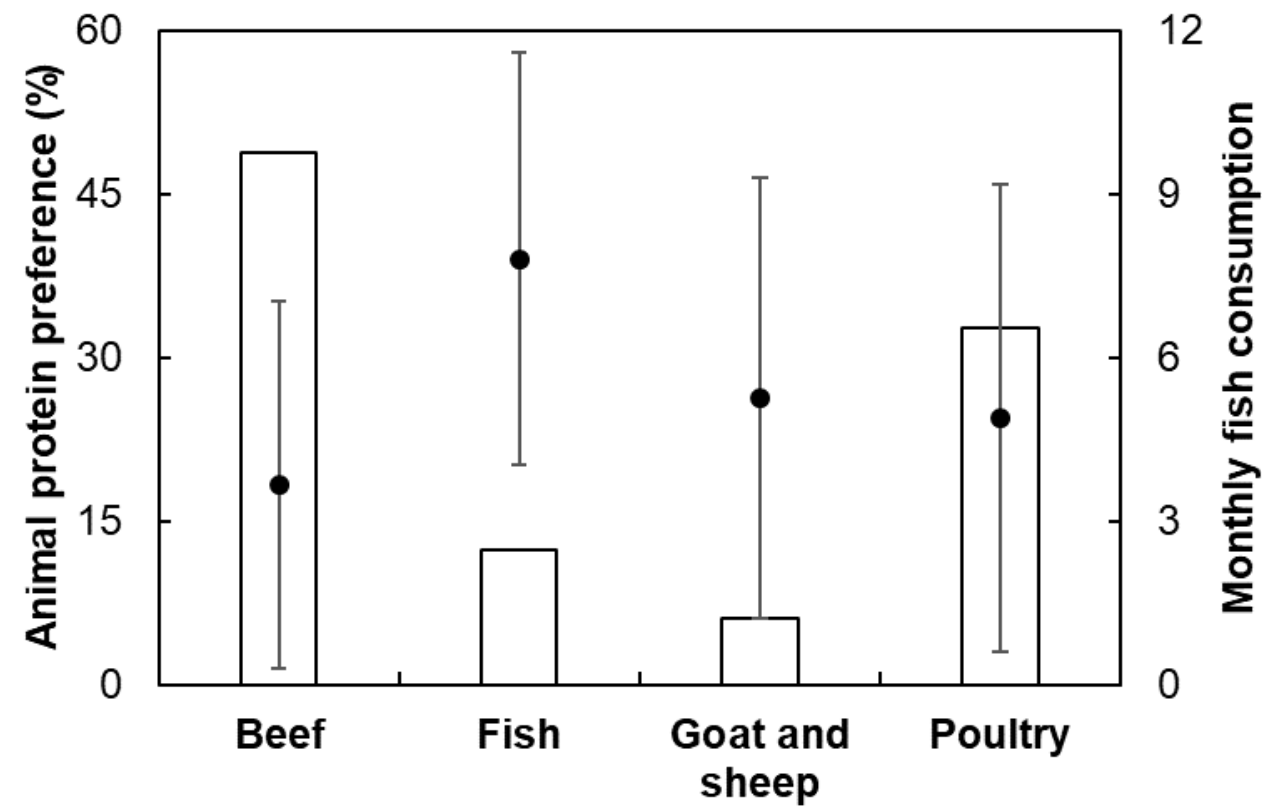

Figure 3. Preference for animal protein type (\%) and monthly fish consumption in Pernambuco's semiarid region in the year 2016. The bars indicate preference for animal protein type and the circles indicate mean values with standard deviation monthly fish consumption.

Analysis of each variable (age, gender, schooling, income and product preference) individually did not show any influence on the level of consumption (Figure 1), however, when correlating these variables into a multiple model, youth (indicated by the youngest age group) showed a negative impact on fish consumption. A preference for fish was the variable that showed the strongest influence, while no distinction was noted between other age groups, between the sexes, nor income levels, according to the model:

Consumption $=4.4983-1.9821$ Youths +4.0481 Preference

$$
(P \text {-value }=0.00005 ; \text { Durbin-Watson }=2.0594)
$$

The model was considered adequate, due to its significant $p$-value and Durbin-Watson statistic indicating that there is no autocorrelation in the sample. It can be affirmed that the average consumption by youths that declared a preference for consuming fish is $6.56 \pm 1.47$ meals per month, whereas the other age groups among those with a preference for fish had an average consumption of $8.55 \pm 1.47$ meals per month. Among interviewees who indicated that an animal protein other 
than fish was preferred, the young interviewees consume $2.52 \pm 1.47$ meals of fish per month while older age groups had averages of $4.50 \pm 1.47$ meals per month.

\section{DISCUSSION}

Due to its chemical constitution, fish meat is recognized as a potential source of essential nutrients for human consumption. Thus, it is possible to highlight their benefits regarding the presence of high digestibility protein, essential amino acids, omega-3 and vitamins (RODRIGUES et al., 2013). These benefits have contributed to a noticeable increase in consumption and preference for fish worldwide (FAO, 2017).

The North and Northeastern regions of Brazil tend to have the nation's highest per capita average fish consumption, which is strongly influenced by these regions' high concentration of the nation's registered artisanal fishermen. This allows for fish to be purchased at a more affordable price due to the highly perishable nature of these foods and the dedicated processing logistics required as compared to other sources of animal protein (SARTORI; AMANCIO, 2012).

Pereira et al. (2010), in his study of the national fishing agroindustry, explains that in 2008 Brazilian supermarkets and hypermarkets were the preferred places for purchasing fish, while all other establishments combined accounted for approximately $65 \%$ of total sales, that obtained in this study. This variation can be associated with the lower final price of the product, since in supermarkets generally sell unprepared fish in natura.

According to Verbeke and Vackier (2005), Verbeke et al. (2007), and Basho and Bin (2010), women account for a greater percentage of fish consumption because they seek health benefits gained from the balanced consumption of this meat, such as the reduced risk factors for a number of conditions such as hypertension, inflammatory and cardiovascular diseases. However, in the present study, we observed no significant differences in the ratio of the amount consumed according to gender, and it can be concluded that it is only associated with the local culture from which the studies were carried out. 
A rise in the number of individuals maintaining a diet of healthy, low-fat, cholesterol-free foods has contributed to an increase in the demand for white meat, the food group to which fish belong (GONÇALVES et al., 2008; SILVA et al., 2012). In agreement with Melo et al. (2011), Tavares et al. (2013) and Devadawson et al. (2015), the disparity found between beef consumption and other proteins may be related not only to competition with other types of meat, but also to demographic factors, as well as local customs and seasonality.

Corroborating the results of this research, the aforementioned authors mention the socioeconomic aspect as a variable that does not influence the consumption of fish in two separate Brazilian States, Bahia and Minas Gerais, as well as in Sri Lanka, in Asia. This fact can be explained due to a preference for buying fish, initially aiming at health benefits, product quality and species (COELHO et al., 2017). While these studies indicate that income and/or economic factors do not present a significant effect on fish consumption, it is essential to maintain and promote campaigns to encourage fish consumption, as well as to promote public investment in order to reduce production costs and, consequently, ensure that fish is always a readily available option for consumers. These and other actions are necessary in order to prevent the economic factor from becoming the deciding factor for consumption decisions, in the short, medium and long term.

\section{CONCLUSIONS}

Fish consumption is directly associated with health benefits, it was possible to observe that the consumption of fish in Pernambuco's semiarid region is influenced by age groups, which we analyzed according to the statistical model. When analyzing consumption according to education and income levels, we were able to verify that neither is associated with a significant difference, although our results suggest a possible minor relation between fish consumption and education level. Our results do indicate that place of purchase is associated with a significant difference in fish consumption, evidencing that the greater consumption is related to 
the direct purchase from fishermen. Fish ranks third among sources of animal protein, falling behind both poultry and beef. Therefore, despite the relatively higher levels of fish consumption in Pernambuco's semiarid region, it remains necessary to highlight the potential for greater consumption and to emphasize the importance and benefits of this food for consumers.

\section{ACKNOWLEDGMENT}

The authors are grateful for the aid granted by the Programa de Educação Tutorial (FNDE).

\section{ETHICS AND BIOSSECURITY COMMITTEE APROVAL}

The study did not require the approval of an institutional ethics committee, since the work was developed with random audience. In addition, all participants in the interviews were aware that the research was part of an academic work.

\section{REFERENCES}

BALBINO, L. C. et al. Evolução tecnológica e arranjos produtivos de sistemas de integração lavoura-pecuária-floresta no Brasil. Pesquisa Agropecuária Brasileira, v. 46 , n. 10, p. 0-0, 2011.

BASHO, S. M.; BIN, M. C. Propriedades dos alimentos funcionais e seu papel na prevenção e controle da hipertensão e diabetes. Interbio, v. 4, n. 1, p. 48-58, 2010.

BRASIL. Ministério da Agricultura, Pecuária e Abastecimento - MAPA. Boletim estatístico de pesca e aquicultura do Brasil 2013 (Brazilian statistical bulletin of fisheries and aquaculture). Brasília: República Federativa do Brasil, 2015.

CARVALHO, T. B. D. et al. (2008). Uma análise da elasticidade-renda de proteína animal no Brasil. In: 46th Congress, July 20-23, 2008, Rio Branco, Acre, Brasil. 
Sociedade Brasileira de Economia, Administração e Sociologia Rural (SOBER), 2008.

COELHO, A. C. S. et al. Fatores que influenciam a compra de peixes por classe social no município de Santarém-PA. Revista Agroecossistemas, v. 9, n. 1, p. 6283, 2017.

DEVADAWSON, C. et al. Socio-demographic factors and fish-eating trends in eastern community, Sri Lanka. Journal of Experimental Biology and Agricultural Sciences, v. 3, n. 5, p. 423-9, 2015.

FAO. 2017. Fishery and Aquaculture Statistics. Global capture production. In: FAO fisheries and Aquaculture Department. Rome. Updated 2017. (www.fao.org/fishery/statistics/software/fishstatj/en). Accessed on 11/11/2017.

GONÇALVES, A. A. et al. Tendência do consumo de pescado na cidade de Porto Alegre: um estudo através de análise de correspondência. Estudos tecnológicos, v. 4, n. 1, p. 21-36, 2008.

Instituto de Economia Agrícola. Produção Animal: Estado de São Paulo e Brasil, 2005 a 2014. Análise e Indicadores do Agronegócio, v. 11, n. 3. 2016.

LÓPEZ-VICENTE, M. et al. Prenatal omega-6: omega-3 ratio and attention deficit and hyperactivity disorder symptoms. The Journal of pediatrics, v. 209, p. 204-211. e4, 2019.

MCCLENACHAN, L. et al. Fair trade fish: consumer support for broader seafood sustainability. Fish and fisheries, v. 17, n. 3, p. 825-838, 2016.

MELO, J. F. B. et al. Comercialização e perfil do consumidor da carne de peixe na região do semiárido de Juazeiro (BA) e Petrolina (PE). Informações Econômicas, São Paulo, v. 41, n. 12, 2011.

MENDES, P.P. Estatística aplicada à aquicultura. Recife: Bagaço, v. 1, p. 265, 1999. 
O'QUINN, T. G. et al. Evaluation of the contribution of tenderness, juiciness, and flavor to the overall consumer beef eating experience. Translational Animal Science, v. 2, n. 1, p. 26-36, 2018.

PEREIRA, M. P. et al. Descrição do sistema agroindustrial brasileiro de pescado. Informações Econômicas, v. 40, n. 3, p. 53-61, 2010.

RIBEIRO-NETO, T. F. et al. Piscicultura familiar extensiva no baixo São Francisco, estado de Sergipe, Brasil/Extensive fish farming in Lower São Francisco River Basin in Sergipe State, Brazil. Acta of Fisheries and Aquatic Resources, v. 4, n. 1, p. 6269, 2016.

RODRIGUES, A. P. O. et al. Piscicultura de água doce: multiplicando conhecimentos. Brasília, DF: Embrapa, 2013.

SALTON, J. C. et al. Integrated crop-livestock system in tropical Brazil: Toward a sustainable production system. Agriculture, Ecosystems \& Environment, v. 190, p. 70-79, 2014.

SARTORI, A. G. O.; AMANCIO, R. D. Pescado: importância nutricional e consumo no Brasil. Segurança alimentar e nutricional, v. 19, n. 2, p. 83-93, 2012.

SILVA, J. C. D. et al. Food-resource partitioning among fish species from a first-order stream in northwestern Paraná, Brazil. Neotropical Ichthyology, v. 10, n. 2, p. 389399, 2012.

SIMOPOULOS, A. P. Evolutionary aspects of diet, the omega-6/omega-3 ratio and genetic variation: nutritional implications for chronic diseases. Biomedicine \& pharmacotherapy, v. 60, n. 9, p. 502-507, 2006.

TAVARES, G. C. et al. Perfil do consumo de pescado na cidade de Belo Horizonte, MG. B. Indústr. anim.[S. I.], v. 70, n. 3, p. 230-236, 2013.

VERBEKE, W.; VACKIER, I. Individual determinants of fish consumption: application of the theory of planned behaviour. Appetite, v. 44, n. 1, p. 67-82, 2005. 
VERBEKE, W. et al. Consumer evaluation of fish quality as basis for fish market segmentation. Food quality and preference, v. 18, n. 4, p. 651-661, 2007.

ZAR, J. H. Biostatistical analysis: Pearson new international edition. Pearson Higher Ed, 2013 .944p. 